\title{
Ombudsmen and administrative justice
}

\author{
by Ann Abraham
}

This article is based on a lecture given to the Society for Advanced Legal Studies on October 27, 2005.

\section{INTRODUCTION}

$\mathrm{T}$ The administrative justice landscape is potentially very wide, and there is so much happening, or about to happen, in this area at the moment. This, along with many developments in the work of my own office at present, means that I have been faced with some difficult choices of what to include in and omit from this article. I have decided to try to achieve three objectives:

1. To enhance your knowledge of who Ombudsmen are, what they do and what, in particular, they bring to the landscape of administrative justice.

2. To share with you some recent cases I have been involved in, where Ombudsmen, and the courts - and in some cases Parliament as well - have all been (and in some respects still are) wrestling with the same issues, and sometimes indeed the same subject matter. In doing so, I want to share some thoughts about how the current administrative justice framework and administrative justice machinery might be better designed to deal with that interface between Ombudsmen and the courts, in everyone's interests, but especially in the interests of our customers.

3. Finally, I would like to look at the broader constitutional picture, and to reflect on the interface with other forms of scrutiny, and in particular with Parliament.

\section{A CHANGING LANDSCAPE}

This is a fascinating time in the development of administrative justice and public law. The Administrative Justice White Paper: Transforming public services: Complaints, Redress and Tribunals, published by the Department for Constitutional Affairs in July 2004, has set a wide agenda. The planned new Administrative Justice Council, evolving from the Council on Tribunals, will keep under review the whole administrative justice landscape, from first instance decision making to the courts, tribunals, ADR and, of course, Ombudsmen.

In 2004 autumn the Law Commission held a seminar on Monetary Remedies in Public Law, involving participants from legal practice, academia, government, ombudsmen and the judiciary. As a result the Commission decided to include in its ninth programme of work a scoping study to look more broadly at remedies against public authorities. In doing so they said that they had;
"... moved beyond thinking about the specific question of monetary remedies to the broad range of remedies that currently exist, including those available to courts, tribunals and ombudsmen, to explore the extent to which changes might be contemplated which could result in a more integrated and straightforward system of resolving disputes involving public authorities."

In 2005 the National Audit Office published a report on Citizens' Redress. Change and reform are certainly in the air.

\section{WHAT THE CITIZEN WANTS}

A good place to start when looking at the administrative justice landscape is with the citizen. What is it that the citizen and service user wants from public authorities? How does that equate with administrative justice?

It seems to me that people want the state at all levels, central and local, to:

- make correct decisions;

- act lawfully;

- administer public organisations well and effectively;

- provide services to a good standard.

When public service providers don't do that, people want an administrative justice system that:

- puts things right as speedily as possible;

- provides appropriate redress/remedies, specific and general;

- does so at reasonable and proportionate cost; and, most importantly,

- extracts the learning from the experience and feeds it back to public service providers to improve decision making and standards of service. 
When I spoke about these issues at the Council on Tribunals conference in Autumn 2004, I called that “appropriate and proportionate dispute resolution", or put another way, "horses for courses". All of us who deliver "administrative justice" have our strengths and weaknesses, whether we work through adversarial systems (courts \& tribunals), inquisitorial systems (ombudsmen), or systems of dispute resolution (eg mediation, conciliation or arbitration). What is important, and therefore where our common interests should lie, is that the system of administrative justice, and administrative justice machinery, should operate in a manner that enables any individual dispute in the administrative justice sphere to get to the place (ombudsman, court, tribunal, mediator, regulator) where it has the best chance of being effectively resolved as quickly as possible. In that way our customers get the best outcome because we all do what we're good at - and what we're best placed to deliver.

\section{THE BENEFITS OF OMBUIDSMEN}

So what are Ombudsmen good at? What are we best placed to deliver, and what is our special contribution to the administrative justice landscape?

The report of the recent Law Commission seminar summarised that very well:

"Ombudsmen offer distinct advantages. They are free, confidential and accessible and perceived by the public as independent. They offer a range of remedies including financial redress, which may take the form of payments of money owed or compensation for quantifiable losses, losses of a non-monetary kind, "botheration" and lost opportunities.

... Although determinations made by an ombudsman are not binding, this did not present a problem in the vast majority of cases. Ombudsman schemes also seek to promote good administration by considering the standards to be expected of public authorities and framing their decision-making accordingly, as well as providing feedback and advice to ensure that errors are not repeated."

The range of remedies available through ombudsmen includes:

- apology;

- specific action (do the repair, transfer a tenant, plant a tree, name a bench in memory of a loved one);

- financial redress - monetary loss, (eg backdate the benefit - with interest, loss of value, loss of opportunity, distress, inconvenience).

However, there is more that Ombudsmen offer after remedies have been applied:

- We follow through, ensuring compliance with recommendations;

- We ensure that others in a similar position are also compensated;
- We make general recommendations for reviews of practice, policy or procedures;

- We issue good practice guidance, eg the Local Government Ombudsman's reports on neighbour nuisance and school admissions and appeals;

- As PHSO I can make special reports to Parliament on issues of systemic maladministration, (eg NHS funding for continuing care, tax credits). These reports are especially appropriate where large-scale or persistent problems are revealed by complaints.

The positive view expressed at the Law Commission event is shared at the highest levels of the legal system. In 2003, the Court of Appeal considered the approach to be adopted by the courts when considering claims for damages under the Human Rights Act 1998. The court went on to say that complainants should generally turn to Ombudsmen, rather than the courts, "at least in the first instance" where they are claiming damages for a breach of human rights caused by maladministration.

Recently I have also noticed a heartening and growing awareness among the judiciary and the legal world more generally of the advantages we offer. As the Council on Tribunals (of which I am an ex officio member as Parliamentary Ombudsman) continues to develop its role in administrative justice, it is building a constructive and productive relationship with the British and Irish Ombudsman Association and collaborating on some projects of mutual interest - such as mapping the landscape of administrative justice and the regulatory environment - and developing principles of good complaint handling.

The Ombudsman's inquisitorial process is now being seen by many as more effective and economical than the traditional court or tribunal adversarial model for arriving at the resolution of certain disputes. Unlike the courts, ombudsmen on the whole do not need hearings. We do not need parties to be represented by lawyers, and we are effective at getting the evidence we need. In many cases ombudsmen are the best and most pragmatic way of resolving the problem.

\section{CURRENT CASES}

Let me turn to some very recent cases in which I have been involved where the courts have also had a role to play - sometimes before, sometimes after, sometimes during the involvement of the Ombudsmen - and invite you to reflect on whether these systems, processes, and remedies worked as well as they might have done in the interests of those on the receiving end of actions of public authorities.

\section{Balchin}

In Autumn 2005 I published a report on the case of $\mathrm{Mr}$ and Mrs Balchin, which revolved around the actions of the Department for Transport and Norfolk County Council. As 
such, the complaint was in both my jurisdiction and that of the Local Government Ombudsman and we each undertook an investigation. Working in close collaboration, we found maladministration both by the Council and the Department and concluded that each must carry an equal share of the responsibility for the hardship caused to the complainants. We recommended that each body should pay $£ 100,000$ to Mr and Mrs Balchin. Both the Council and the Department accepted our recommendations.

However, the legislative framework meant that collaboration with my Local Government Ombudsman colleague was not as easy as it should have been. The relevant legislation requires that the Local Government Ombudsman and I publish separate reports. While both reports can be read individually, it is only when they are read together that the full story can be understood. For this reason each report has the other annexed to it.

This experience illustrated the need for reform of the legislation covering aspects of the working arrangements of public sector Ombudsmen, something which we have been seeking for some time. The current restrictions on our ability to work together mean that we cannot easily provide the sort of joined-up service that we should be able to give all citizens who have complaints which cross more than one Ombudsman jurisdiction.

Change, I am pleased to say, is finally on its way, in the form of a Regulatory Reform Order on which the Cabinet Office has recently consulted, which will allow the Local Government Ombudsmen and the Parliamentary and Health Service Ombudsmen to carry out joint investigations much more easily. This clearing of the undergrowth in one part of the administrative justice landscape will, I believe, be a source of real benefit to the citizen.

But Mr and Mrs Balchin's story goes back a long way and has also involved the courts. Their complaint related to a series of decisions by the local authority not to purchase their home in the 1987, 1990 and 1992. My report was the fourth by a Parliamentary Ombudsman. Mr and Mrs Balchin first complained to the Parliamentary Ombudsman in early 1994. My predecessor but one issued the first report on the case in December 1994. He did not find maladministration by the Department of Transport.

That first report - and two subsequent reports in 1997 and 2000 - were quashed following judicial review proceedings in the High Court brought by Mr Balchin. In his judgment in 1994 Mr Justice Sedley, as he then was, commented on the local authority's decision which he described as "highly questionable" and "a textbook example of a fettered discretion" by a local authority. Would it not have been better all round if at that point in the consideration of the case there had existed a mechanism for the High Court Judge to pass the case directly to the Local Government Ombudsman - who was much better placed to deliver a remedy to $\mathrm{Mr}$ and $\mathrm{Mrs}$
Balchin than the High Court would ever be - and ask him to have a look at it?

\section{Far Eastern civilian internees - "A debt of Honour"}

The next case involves both the courts and the Parliamentary Ombudsman - but in this instance they have been looking at different aspects of the same events.

On July 12, 2005, I laid before Parliament a special report entitled A Debt of Honour, my report of the investigation I had conducted into complaints about the administration of the ex gratia scheme for British civilians interned by the Japanese during the Second World War. The complaints I had received and investigated related to a decision to introduce a new eligibility criterion - that to qualify for payment under the scheme, a claimant had to have been born in the UK or have had a parent or grandparent born here - many months into the operation of the scheme.

I found that the actions of the Ministry of Defence had constituted maladministration in four respects: in the overly quick manner in which the scheme had been devised; in the lack of clarity in the announcement of the scheme; in the failure to ensure that the introduction of the new criterion did not have an adverse impact in terms of equal treatment; and in the failure to inform claimants that the eligibility criteria had been changed. I recommended that the Ministry of Defence review the operation of the scheme and reconsider the position of those who had been adversely affected by the maladministration. I also recommended that an apology be made to those refused payment and that that regret should be expressed tangibly.

But interestingly, this is another case where the courts have also been involved. First, a judicial review brought by the Association of British Civilian Internees Eastern Region challenged the legality of the Government's decision to introduce a bloodlink criterion as a requirement for eligibility for certain claimants. ABCIFER contended that the decision was disproportionate and/or irrational, involved a breach of legitimate expectation and/or was conspicuously unfair and an abuse of power. The action failed, first in the High Court and in the Court of Appeal in 2003. Second, in a more recent High Court judgment in June 2005 in a judicial review case brought by an internee (now in her 80s), and supported by the Commission for Racial Equality against the Secretary of State for Defence, the scheme was found to be unlawful in that it directly discriminated against people of non-British national origin.

It was also found that the Secretary of State was in breach of his duties under section 71 of the Race Relations Act, that is "to eliminate unlawful racial discrimination and to promote equality of opportunity and good relations between persons of different racial groups." I will say no more about that case which I understand is the subject of appeals by both parties, and a cross appeal. 
The judicial review on the racial discrimination point was a different complaint and did not affect my investigation. But the existence of the judicial review on the lawfulness of the scheme exercised us considerably in identifying what space was left for us properly to investigate a complaint - albeit from someone unconnected with the organisation that brought the judicial review - of what we described in the report on the case and in the special report to Parliament as "maladministration short of unlawfulness". I will not go into the detail of that here, but for Ombudsmen scholars I would refer you to paragraphs 11-39 and 129-34 of my report, which deal with these issues in detail, and specifically paragraph 131 which says:

"Questions of legality are for the courts to decide and I do not seek to question or comment on their findings. Questions of maladministration are for me to decide."

It did occur to us that we might have been able to conduct a more comprehensive investigation if the judicial review had never been brought. The Court of Appeal judgment clearly sympathised with the appellants.

"Naturally, we feel very great sympathy for all those who suffered appalling ill-treatment at the hands of the Japanese during their captivity. We also well understand that many civilians had their hopes of receiving compensation raised by [the Minister's] announcement of November 7, 2000, and that they have been extremely disappointed, and indeed angered, by what they see as a subsequent and unfair change of heart on the part of the Government. But anyone who seeks to challenge as unlawful the content of a non-statutory exgratia compensation scheme faces an uphill struggle. We do not think that the introduction of this scheme was well handled by the Government. But for the reasons that we have given, the appellant has failed to satisfy us that the scheme was unlawful."

Would it not have been better if the judges had decided the case would be better dealt with by the Parliamentary Ombudsman and handed it over?

\section{Tax credits}

The final area of our casework I want to refer to is the topical subject of tax credits. Over the past two years, a high proportion of the cases referred to me as Parliamentary Ombudsman has concerned Working and Child Tax Credits. In June 2005, I therefore presented a special report to Parliament, Tax credits: putting things right. My report's recommendations covered the way overpayments are handled, communication with customers, the steps that should be taken to reduce the risk of financial hardship, the provision of easier and quicker customer access to staff who could address problems and queries, and effecting prompt and efficient complaint handling. I also recommended that consideration should be given to writing off all excess and overpayments caused by official error during 2003-05.
The Paymaster General has responded to my report, promising improvements to the administration of the system and to the quality of information to claimants, but not accepting all my recommendations. I, of course, welcome the Government's assurances that they are taking action to improve the administration of the tax credits system. I have also had useful and constructive discussions with the Revenue about the future handling of complaints and I am hopeful that we will see a reduction in cases in due course, although that time might be some way off.

One of the issues discussed in that report is the question of automatic recovery of overpayments of tax credits. It has been suggested by others, not by me, that automatic recovery is unlawful because it is a fettering of discretion. I have said that whether or not it is unlawful (and I couldn't possibly comment on that), it is certainly maladministrative because it is unfair and a fettering of discretion. It is possibly another example of "maladministration short of unlawfulness" - unless of course the courts decide that no reasonable Ombudsman could ever reach that conclusion?

\section{A CONSTITUTIONAL CHALLENGE?}

That leads me to some interesting questions about the constitutional issues in all of this. The Parliamentary Public Administration Select Committee have, as they should, taken a strong interest in some of these recent cases. The success of the Parliamentary Ombudsman system depends on there being a clear understanding by all involved - and particularly the bodies complained against - of the Ombudsman's constitutional position and role in dealing with complaints. There, the story is distinctly mixed.

In the case of the Far East civilian internees, the Ministry of Defence did not accept all of my findings and has only agreed to implement the latter two recommendations. This decision by the Government is of considerable regret to me. The position of the Revenue on the recommendations in the tax credits report is still not entirely clear. When the Chairman of the Revenue appeared to suggest in response to a question from a member of the Treasury Select Committee Sub Committee that he was challenging the Ombudsman's finding of maladministration, he was challenged pretty firmly back by a member of the Committee who said "Isn't the Ombudsman the arbiter of maladministration?"

But if Government makes a habit of challenging the Ombudsman's conclusions on what constitutes maladministration, where does that get resolved? In Parliament? In the courts? Occasionally maybe, but not as a matter of routine, and preferably not at all.

Does not the Ombudsman concept - in the public sector at least - depend on an acceptance by all concerned that unless she takes leave of her senses and reaches conclusions that no reasonable ombudsman could ever reach, the Ombudsman is indeed the "arbiter of maladministration." It is after all her trade, and most High 
Court judges only look at an ombudsman case once or twice in a lifetime.

My predecessors and I have not needed or sought enforcement powers because the system has worked pretty well for nearly 40 years. However, if departments get used to disputing my findings, I believe that the landscape of administrative justice will change radically, and not to the advantage of the user of public services. I am certainly not claiming that there is a constitutional battle about to break out over the role of the Parliamentary Ombudsman, but it always is possible, with the best will in the world, for simple misunderstandings to lead to more serious problems. We must not let this challenge turn into a crisis.

\section{The place of Parliament}

I am reassured by the fact that I am not alone in facing this challenge. I am very fortunate in that, when my office was established in the 1960s, Parliament decided to put in place a number of mechanisms to support, and scrutinise, the work of the ombudsman - a select committee and the requirement for complainants to ask their MP to refer complaints (the latter is incidentally not the case with my other role as Health Service Ombudsman for England). I have sometimes felt frustrated when explaining the complexity of my title and the extra syllables that the word Parliamentary brings with it. The "MP filter" hardly makes for easy and rapid access to the services of my Office.

However, recent events have clearly revealed the value of the Ombudsman's link with the legislature. In many respects, good relations with Parliament are just as important for ombudsmen as our relations with the courts. It is Parliament that holds ministers to account on policy, implementation and service delivery, and there are a number of ways in which it can support me.

Conversely, the work of ombudsmen, with its focus on individuals and the impact of policy implementation, can complement and strengthen the scrutiny carried out by committees in both Houses. For example, the Public Administration Select Committee is taking a continuing interest in the Debt of Honour report, and a further session on tax credits is likely. In this sense, we can see not just an administrative justice landscape, but a broader space shared with the executive and with the legislature.

\section{A better map needed}

My optimism about the growing understanding of our role in some parts of the judiciary and Parliament does not mean that I am satisfied with the present state of the administrative justice landscape. The July 2004 White Paper envisages a major role for the new Administrative Justice Council which would mean that it would be responsible for, as well as continuing statutory supervision of tribunals, "taking full account of the broader landscape of administrative justice". In detail this would include the responsibility to:
- keep under review the performance of the administrative justice system as a whole drawing attention to matters of particular importance or concern;

- review the relationships between the various components of the system (in particular ombudsmen, tribunals and the courts) to ensure that these are clear, complementary and flexible;

- identify priorities for, and encourage the conduct of, research; and

- provide advice and make recommendations to government on changes to legislation, practice and procedure which will improve the workings of the administrative justice system.

The underlying principle of all this is that the system needs to be made more readily navigable for the user. That implies that cases can be transferred easily and quickly between parts of the system, for instance from courts to ombudsmen, or from tribunals to ombudsmen. It should be established at an early stage what is the most appropriate and proportionate way of resolving a dispute or complaint. The legislation does not make that easy at the moment; I think the Administrative Justice Council will have its work cut out, but it is vital that it succeeds.

One problem is that "administrative justice" as a concept is not easily defined. Many tribunals are concerned with relations between citizen and state, clearly working to ensure that there is a level playing field between the might of the state in its various forms and the interest of the individual citizen and service user. But other tribunals are concerned with disputes between citizens, and some are mixed. Similarly, ombudsmen come in all shapes and sizes, and many in the representative body of ombudsmen, the British and Irish Ombudsman Association, are concerned with the private sector.

Some ombudsmen offices are well established and clearly form part of the administrative justice landscape: the UK Parliamentary Ombudsman and the English Local Government Ombudsmen, and the Scottish and Welsh Public Services Ombudsmen and the Northern Ireland Ombudsmen. There are also a number of specialist ombudsmen who deal with complaints about the prison service and about social (and some private) landlords.

Yet in education and in other important areas of the public service there are few ombudsmen schemes or none at all. There are private sector ombudsmen for financial services and the telecommunications industry and the removals industry and for surveyors, but not for the utilities or the retail sector generally. This is an uncoordinated system in itself, and its links to the civil justice system and where relevant to other parts of the administrative justice system are not at all clear. 
Devolution has enabled ombudsmen dealing with devolved and local government matters in Scotland, Wales and Northern Ireland to combine their functions in ways which make a great deal of sense. Yet I am still responsible for non-devolved matters and the main features of the landscape are still not easy to summarise.

The British and Irish Ombudsman Association would have liked the White Paper to have proposed an obligation on the Council to:

"keep all [ombudsman] schemes under review with the aim of ensuring that there is both clarity and choice for users wishing to pursue their grievance or dispute. We also consider that there may be benefits for users if the Council were to verify applications for use of the title 'Ombudsman' using published criteria of independence and quality, such as the British and Irish Ombudsman's Association's criteria for recognition of Ombudsman schemes.'

That did not prove possible for the DCA, but the principle of preserving the integrity of the concept of an ombudsman is an important one at a time when more and more ombudsmen bodies are being created.

It seems to me that all of us - ombudsmen, tribunals, courts, other ADR providers - are part of the same administrative justice landscape. We provide a variety of means to an end, not a series of successive and increasingly higher hurdles for our customers to clear, and whereas we might provide choices for our customers, we should not be a set of confusing and incoherent alternatives. There is no hierarchy of justice - only the most appropriate justice in each case.

So we need a better map of the ombudsman and the wider administrative justice landscape, and agreement on who does what best. And even history argues for a proper review. As it happens, April 1, 2007 will see be the 40th anniversary of the establishment of the Parliamentary Ombudsman. Recent years have seen a series of piecemeal and patchwork changes to the Ombudsmen arrangements in the UK. It seems to me that the time has now come for a more comprehensive, coherent and in depth review.
Just think what has happened since the Parliamentary Ombudsman was created in 1967:

- $\quad$ entry into Europe - EU law;

- civil justice reforms/ADR;

- devolution;

- Human Rights Act;

- Data Protection and Freedom of Information Acts;

- a wholesale shift in the way that public services are delivered - in partnerships between central and local government providers, between public and private and voluntary sectors, and against a backdrop of an ever changing regulatory environment.

In the light of all that it would be astonishing if the arrangements first put in place in 1967, and largely unchanged since then, did provide a fit for purpose Ombudsman for the 21 st century.

\section{CONCLUSION}

So, in conclusion, I would say that we live in interesting times in administrative justice. The constituent parts are talking to each other much more than they used to, and there is a real chance, with the Administrative Justice Council, of making it a much more coherent and accessible system. But the various components are not finding it easy to work together, partly because the landscape still lacks overall shape and boundaries are uncertain. The customer finds it hard to navigate the system and gain redress.

A comprehensive review of public sector Ombudsmen arrangements in the UK in the run up to the 40th anniversary of the establishment of the Parliamentary Ombudsman would be a good way to get back on track. It would also be an excellent 40th birthday present for the Ombudsman.

Ann Abraham

UK Parliamentary Ombudsman and Health Service Ombudsman for England 